\title{
Rock glacier characteristics serve as an indirect record of multiple alpine glacier advances in Taylor Valley, Antarctica
}

\author{
Kelsey Winsor ${ }^{1, a}$, Kate M. Swanger ${ }^{1}$, Esther Babcock ${ }^{2}$, Rachel D. Valletta ${ }^{3, b}$, and James L. Dickson ${ }^{4, c}$ \\ ${ }^{1}$ Department of Environmental, Earth and Atmospheric Sciences, University of Massachusetts Lowell, \\ Lowell, MA 01854, USA \\ ${ }^{2}$ Logic Geophysics \& Analytics LLC, Anchorage, AK 99508, USA \\ ${ }^{3}$ Department of Earth and Environmental Sciences, University of Pennsylvania, Philadelphia, PA 19104, USA \\ ${ }^{4}$ Department of Earth, Environmental and Planetary Sciences, Brown University, Providence, RI 02912, USA \\ anow at: School of Earth and Sustainability, Northern Arizona University, Flagstaff, AZ 86005, USA \\ b now at: Franklin Institute, Philadelphia, PA 19103, USA \\ ${ }^{c}$ now at: Division of Geological and Planetary Sciences, California Institute of Technology, Pasadena, CA 91125, USA
}

Correspondence: Kate M. Swanger(kate_swanger@uml.edu)

Received: 3 June 2019 - Discussion started: 18 June 2019

Revised: 2 November 2019 - Accepted: 4 November 2019 - Published: 2 January 2020

\begin{abstract}
The geomorphic record indicates that alpine glaciers in the McMurdo Dry Valleys of southern Victoria Land, Antarctica, appear to advance during interglacial periods in response to ice-free conditions in the Ross Sea. Few records of these advances are preserved and/or subaerially exposed, complicating the interpretations of regional glacier response to climate changes. Here, we present geophysical and geochemical analyses of a rock glacier that originates from icefalls fed by alpine Doran Glacier in central Taylor Valley. The rock glacier exhibits a trend of increased weathering of granitic clasts via ventifaction and grussification down-flow. Meltwater ponds on the rock glacier exhibit variable salinity that ranges from freshwater to higher than seawater, with the highest salinity pond near the rock glacier toe. Ground-penetrating radar analyses reveal the feature to possess a primarily clean ice interior, with layers of englacial debris. Stable isotopic data from three ice cores support a glacial origin for the ice within the rock glacier. These data suggest that the current morphology of the rock glacier is the result of multiple events of increased ice contribution caused by advances of Doran Glacier, which is the main source of ice to the rock glacier. We therefore demonstrate the potential of ice-cored rock glaciers to record multiple advances and retreats of Dry Valley glaciers, permitting the interpretation of glacial responses to Pleistocene and Holocene climate change even where direct records are not present.
\end{abstract}

\section{Introduction}

Alpine glaciers in East Antarctica's McMurdo Dry Valleys (Fig. 1) are important components of the regional hydrologic cycle (Lyons et al., 1998). In some areas, recent warming has caused melting of both alpine glaciers and ground ice, suggesting that modern ice behavior in the Dry Valleys might reflect global temperature changes (Fountain et al., 2006; Hoffman et al., 2016). Partnered with an increase in both stream incision rates and lake levels throughout Taylor and surrounding valleys, this activity has suggested an invigoration of modern Dry Valley hydrology (Fountain et al., 2014; Guglielmin and Cannone, 2012; Levy et al., 2013; Macdonell et al., 2013). However, the geologic record of Dry Valley alpine glacier behavior previous to the Holocene is generally limited to isolated moraines and proglacial lake deposits that indicate prior glacial advances (e.g., Higgins et al., 2000; Swanger et al., 2017).

Here, we examine a Taylor Valley rock glacier that extends from an icefall fed by alpine Doran Glacier of the Kukri Hills (Figs. 1 and 2). Rock glaciers (flowing mixtures of ice, rock, and sediments) are common throughout the Dry Valleys and other ice-free regions in Antarctica (Fukui et al., 2008; Hassinger and Mayewski, 1983); however their age, origin, and geomorphic significance remains poorly constrained in many locations. In general, rock glaciers can form 


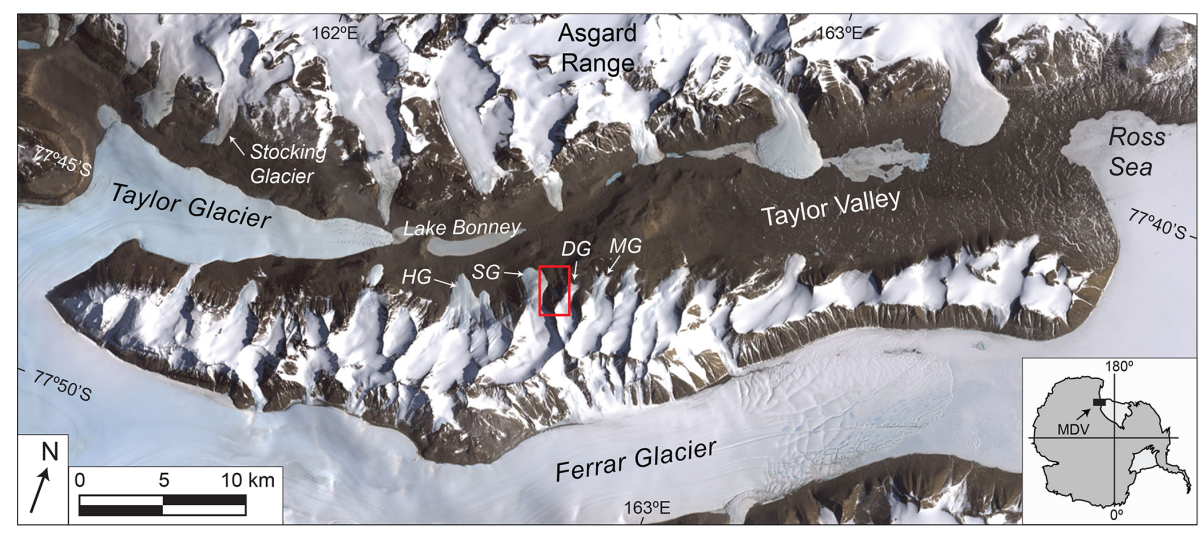

Figure 1. Satellite image of the McMurdo Dry Valleys (MDV), with inset indicating location in Antarctica. HG: Hughes Glacier; SG: Sollas Glacier; DG: Doran Glacier; and MG: Marr Glacier. The red rectangle shows the location of rock glacier (Fig. 2). Public domain Landsat 7 imagery acquired on 18 December 1999 courtesy of NASA Goddard Space Flight Center.

through periglacial processes (permafrost and ice-rich talus) and through glacial processes (burial of glacier ice by talus and alluvium) (Anderson et al., 2018; Clark et al., 1998; Hamilton and Whalley, 1995; Knight et al., 2019). Therefore, rock glaciers might provide information on past glacial fluctuations, permafrost development and degradation, and erosion rates.

At the study location in Taylor Valley, because ice is fed to the rock glacier from the lateral margin of Doran Glacier, intervals of rock glacier growth and advance are limited by the extent of Doran Glacier and its ability to advance to the top of a bedrock cliff (Fig. 3). To identify discrete episodes of Doran Glacier advance, we examine the internal structure using ground-penetrating radar (GPR), stable isotopic and major ion chemistry of buried ice and meltwater ponds, and surface weathering characteristics of the associated rock glacier. This rock glacier provides a unique chronological marker because it records multiple generations of rock glacier advance, which in turn record multiple advances and retreats of its source glacier.

\section{Geologic setting}

Taylor Valley is the most well-studied area of the Dry Valleys, an arid region predominantly free of surface ice (Fig. 1). At the western end of the valley, Taylor Glacier flows from the Taylor Dome of the East Antarctic Ice Sheet, and to the east the valley is bounded by the Ross Sea. Taylor Glacier terminates $\sim 35 \mathrm{~km}$ from the Ross Sea coast, into the west lobe of Lake Bonney, a $40 \mathrm{~m}$ deep, stratified lake with a high salinity gradient (Poreda et al., 2004; Wagner et al., 2010). South of this lake, a $15-20^{\circ}$ slope rises $\sim 200 \mathrm{~m}$ to a bedrock platform. Here, Sollas Glacier flows north for $\sim 8 \mathrm{~km}$ from the Kukri Hills and spreads onto a low-angle bench, reaching a width of $\sim 1400 \mathrm{~m}$ and terminating at $\sim 440 \mathrm{~m}$ a.s.l. (above sea level). To the east, a steep-walled arête separates Sollas
Glacier from the smaller Doran Glacier, which flows north, is $\sim 3 \mathrm{~km}$ long, and terminates at $\sim 840 \mathrm{~m}$ a.s.l. (Figs. 1 and 2).

Along its lower eastern margin, the Sollas Glacier terminates against a small, ice-cored moraine that includes stratified, dipping sediments (Fig. 2). Adjacent to the eastern margin of Sollas Glacier lies a narrow gulley with unconsolidated debris and isolated large boulders. The east side of the gulley is diamict-covered bedrock, which forms a steep slope that rises above the Sollas Glacier surface (Higgins et al., 2000). At the top of this slope is the rock glacier. Because the ice-cored debris and exposed icefalls are geomorphically connected, both are included in the mapped extent for the rock glacier (Fig. 2). The rock glacier extends $\sim 1.2 \mathrm{~km}$ from $\sim 1000$ to $550 \mathrm{~m}$ a.s.l., beginning at the Doran Glacier icefalls. The surface of the uppermost $\sim 600 \mathrm{~m}$ of the rock glacier is currently exposed ice. Blocks of ice, both with and without bubbles, and cobble- to boulder-sized clasts are present in this upper section of the rock glacier. The lowermost $\sim 600 \mathrm{~m}$ of the rock glacier is debris covered (Fig. 2). The debris-covered section has a concentric lobate form with hummocks and multiple steps and risers, indicative of active flow. Surface debris cover is generally thin, ranging from several centimeters in the upper portion of the rock glacier to $>30 \mathrm{~cm}$ near the toe (sediment cover thickens down-flow). Contraction cracks occur throughout the feature, and in at least one location clean ice is exposed within a vertical crack, showing the sharp contact between the buried ice and the overlying sediments. Along the eastern margin of the upper rock glacier, a steep-walled ice-cored ridge (similar in morphology to an ice-cored moraine) extends up-flow for $\sim 300 \mathrm{~m}$, buttressing the eastern margin of the modern exposed ice (Figs. 2 and 3b). The height of the rock glacier could be estimated along the western margin where it terminates on an exposed bedrock surface. At this location, the rock glacier margin is $10-12 \mathrm{~m}$ in height. 


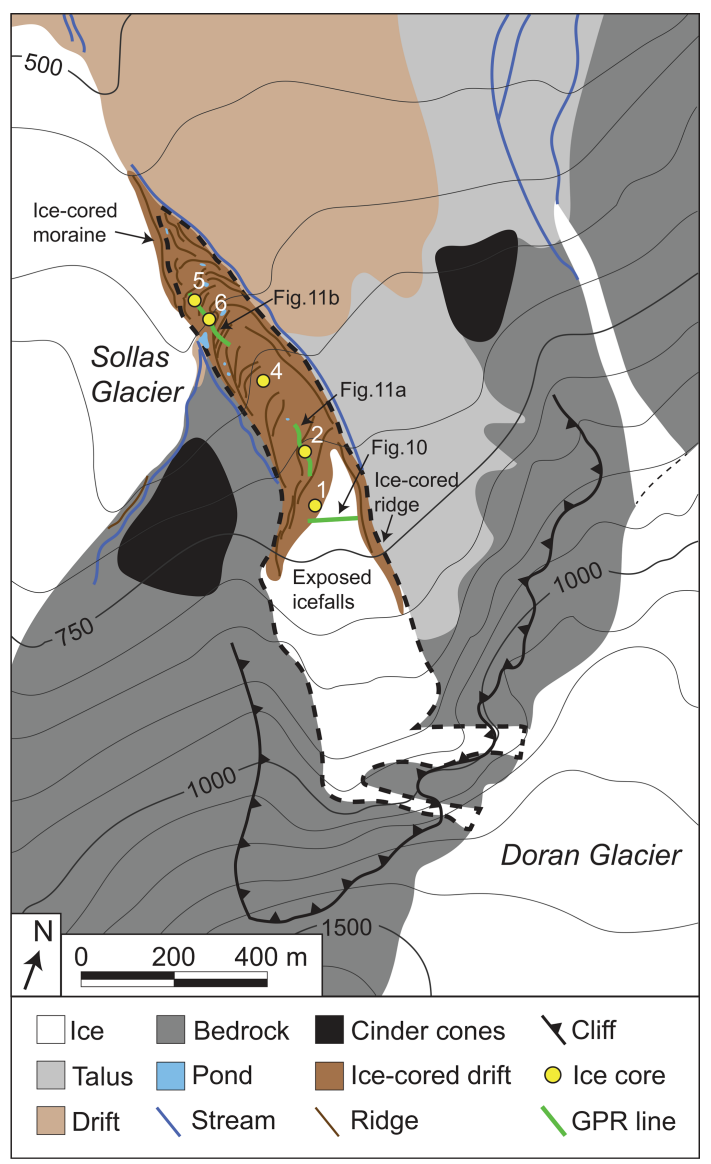

Figure 2. Geomorphic map of the modern rock glacier (outlined in the large black dashed line) and surrounding terrain. Contour interval: $50 \mathrm{~m}$. Ice cores SLI-15-01, SLI-15-04, and SLI-15-05 are from buried ice (labeled 1, 4, and 5). SLI-15-02 and SLI-15-03, and SLI-15-06 and SLI-15-07 are duplicate cores taken from two large frozen ponds (only 2 and 6 labeled). Ground-penetrating radar (GPR) lines are shown in green; one line transverse to rock glacier flow (Fig. 10) and two lines longitudinal to flow (Fig. 11).

Nearly vertical bedrock cliffs $(\sim 100 \mathrm{~m}$ in height) divide Doran Glacier from the rock glacier and are the main source of rockfall material to the landform. This region of Taylor Valley is dotted with extinct Pliocene-Pleistocene cinder cones ${ }^{40} \mathrm{Ar} /{ }^{39} \mathrm{Ar}$ dated by Wilch et al. (1993). These cinder cones also serve as source material for talus near Sollas and Doran glaciers. To the southwest of the rock glacier is a very steep cinder cone talus slope dated to $2.19 \pm 0.04 \mathrm{Ma}$ (Fig. 3a), which, while topographically isolated from the rock glacier at present, may have sourced mafic cobbles to the rock glacier area in the past. A second cinder cone, dated to $3.57 \pm 0.14 \mathrm{Ma}$, is located east of the rock glacier (Fig. 3a). North of the rock glacier, where the ground surface flattens to nearly horizontal, the ground cover is dominated by mafic cobbles. These cobbles are commonly polished, sculpted, and/or pitted and are often underlain by salt efflorescences that can reach over $5 \mathrm{~mm}$ in thickness. In addition to the cin-
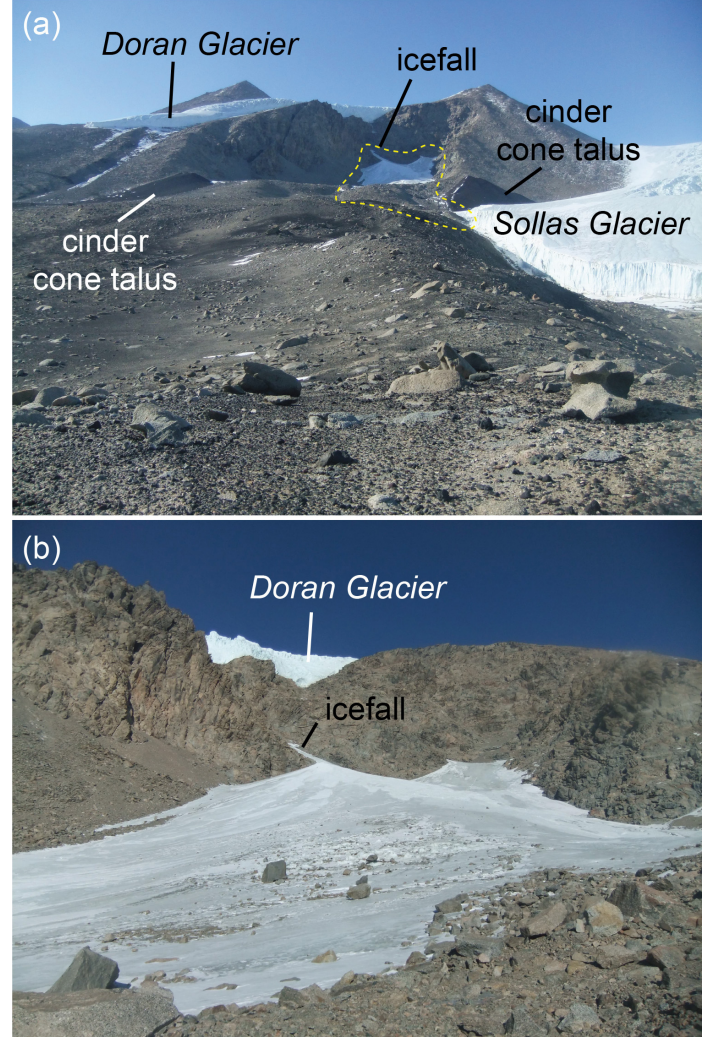

Figure 3. Icefall originating from Doran Glacier and accumulating to form the rock glacier. (a) View from base of Sollas Glacier, with rock glacier visible within yellow dashed line. Note presence of cinder cone talus slopes. (b) View from boundary between debriscovered ice and the modern exposed icefalls.

der cones, several mafic dikes visibly cross-cut the granitic bedrock of the arête east of Doran Glacier (Fig. 3a). Just to the northeast of the rock glacier is a grussified granitic boulder field with significant ventifaction, and the landscape is incised by a network of contraction cracks.

\subsection{Glacial history of Taylor Valley}

Geomorphic evidence for Taylor Glacier advances occurs on the Taylor Valley walls and floor. Recent advances of Dry Valley outlet and alpine glaciers are correlated with the presence of open water in the Ross Sea, which occurs during interglacial periods when the Ross Ice Shelf retreats (Naish et al., 2009). Thus, the outlet Taylor Glacier, in addition to the smaller alpine glaciers, appear to reach relative maxima during warm intervals due to higher precipitation and/or lower ablation rates (Higgins et al., 2000; Hoffman et al., 2016; Marchant et al., 1994; Swanger et al., 2017). Algal carbonates originating in proglacial lakes suggest that Taylor Glacier advanced during Marine Isotope Stages (MIS) 5, 7, 9, and possibly 11 (Higgins et al., 2000). The siltand clay-rich Bonney drift marks the Taylor Glacier mar- 
gin maximum during the last interglacial and is found up to $\sim 300$ m a.s.l. in central Taylor Valley $(\sim 140 \mathrm{~m}$ below the Sollas Glacier toe) (Higgins et al., 2000). Using cosmogenic ${ }^{3} \mathrm{He}$ exposure dating, Swanger et al. (2017) correlated the outermost moraine associated with Stocking Glacier $(17 \mathrm{~km}$ west of Sollas Glacier) to an advance during MIS 11 (Fig. 1). High-elevation deposits of Taylor and Ferrar outlet glaciers have also been dated to approximately 3-4 Ma (Staiger et al., 2006; Swanger et al., 2011). Many other geologic records of local ice advance and retreat are restricted to the last 20000 years and show Holocene advances, which in many cases surpass glacial extents in MIS 2 (Christ and Bierman, 2019; Hall et al., 2000).

\section{Methods}

\subsection{Ice coring and sampling}

We extracted seven shallow ice cores of buried ice and frozen meltwater ponds along a $500 \mathrm{~m}$ long transect down the centerline of the rock glacier in early November 2015 . Three of the cores (SLI-15-01, SLI-15-04, and SLI-15-05) were from buried ice and measured 1.5-2.3 $\mathrm{m}$ in length (Figs. 2 and 4 and Table 1). The remaining four cores (SLI-15-02, SLI-1503, SLI-15-06, and SLI-15-07) were taken from two frozen ponds on the surface of the rock glacier, and each measured $<1.5 \mathrm{~m}$. Core SLI-15-03 was a duplicate of SLI-15-06, and core SLI-15-07 was a duplicate of -06. The depth of coring was limited by debris and equipment. Ice cores were taken with a $7.6 \mathrm{~cm}$ diameter SIPRE hand auger. In addition to the seven ice cores, 15 hand samples were gathered from the upper $15 \mathrm{~cm}$ of the buried ice, the surface ponds, and the exposed icefalls of the modern glaciers, Doran and Sollas. (Tables 1 and 2). Frozen hand samples were collected using a clean, stainless-steel ice pick or a trowel covered in a clean Whirl-Pak bag. Buried ice hand samples were gathered from 5 to $15 \mathrm{~cm}$ depth after removing the upper $5 \mathrm{~cm}$. All surface pond samples were taken from 3 to $5 \mathrm{~cm}$ depth in the center of the pond ice, after manually removing the upper $3 \mathrm{~cm}$ of ice. All ponds, except L3, were frozen at the time of sampling. Pond L3 was beginning to thaw and a $\sim 10 \mathrm{~cm}$ layer of slush-ice topped solid ice below. Despite this early thaw, the ice was solid enough to walk on and we sampled slush-ice from the pond center at $3-5 \mathrm{~cm}$ depth. All samples were packed frozen in sterile Whirl-Pak bags. From McMurdo Station, samples were shipped frozen to the University of Massachusetts Lowell (if sediment-rich) or the National Ice Core Laboratory (NICL) in Lakewood, Colorado (if relatively clean). Subsamples for isotopic and elemental analyses were collected using the facilities at NICL, where laboratory storage freezers maintained sample temperatures below $-20^{\circ} \mathrm{C}$.

\subsection{Major ion analyses}

Samples were stored frozen in HDPE bottles in the field, during transit, and in the laboratory. When ready for processing, samples were thawed and two aliquots were removed - one for cation and one for anion analyses. The aliquot allocated for cation analyses was acidified with $\sim 0.5 \%$ trace-metalgrade $\mathrm{HCl}$. Major ion analyses were performed at the University of Colorado Boulder, using ion chromatography for anion samples and an inductively coupled plasma optical emission spectrometer (ICP-OES) for cation samples. Species analyzed were $\mathrm{Br}^{-}, \mathrm{Ca}^{2+}, \mathrm{Cl}^{-}, \mathrm{F}^{-}, \mathrm{Fe}, \mathrm{K}^{+}, \mathrm{Mg}^{2+}, \mathrm{Mn}, \mathrm{Na}^{+}$, $\mathrm{NO}_{2}^{-}, \mathrm{NO}_{3}^{-}, \mathrm{PO}_{4}^{3-}, \mathrm{Si}$, and $\mathrm{SO}_{4}^{2-}$.

\subsection{Stable isotope analyses}

All ice samples were kept frozen until melted in airtight containers and then stored in $4 \mathrm{~mL}$ HDPE bottles. All bottles were pre-rinsed in a $10 \%$ ACS-grade nitric acid bath and triple rinsed with deionized water before packing, when the samples were sealed and refrozen until analyzed. Stable isotopic analyses $(n=78)$ were conducted using an isotope ratio mass spectrometer at the Boston University Stable Isotope Laboratory. Analyses for $\delta^{18} \mathrm{O}$ were performed via $\mathrm{CO}_{2}$ equilibration, and deuterium analyses were performed via pyrolysis using a GVI ChromeHD ${ }^{\mathrm{TM}_{\mathrm{S}}}$ sstem. Analytical precision for both measurements is typically \pm 0.1 . Isotope values are presented as per mil (\%o) relative to Vienna Standard Mean Ocean Water (VSMOW).

\subsection{Ground-penetrating radar}

\subsubsection{Data collection}

We used a Geophysical Survey Systems, Inc. (GSSI) groundpenetrating radar (GPR) system with a SIR-3000 controller to image the subsurface at the field site. We surveyed one longitudinal transect $(500 \mathrm{~m})$, composed of multiple lines, down the rock glacier from the highest ice core site to the lowest (Fig. 2). We also collected one west-east transverse GPR line $(120 \mathrm{~m})$ at the boundary between debris-covered ice and exposed ice. The line extends across $\sim 20 \mathrm{~m}$ of debris-covered ice and then onto the modern icefalls, stopping at the base of the east-lateral ice-cored ridge (Fig. 2). We collected data with $200 \mathrm{MHz}$ and $400 \mathrm{Mz}$ shielded antenna units, which are both configured in a single housing unit. For $200 \mathrm{MHz}$ antenna, we took 2048 samples per trace, with a time window of 350-700 ns and trace spacing of $0.05 \mathrm{~m}$. The same sample parameters for the $400 \mathrm{MHz}$ antenna were 4096 samples per trace, $150-500 \mathrm{~ns}$ window, and $0.1 \mathrm{~m}$ trace spacing. For both antennae, stacking was four and trace gain was $-20 \mathrm{~dB}$.

Typical surface roughness of rock glaciers prevents effective ground coupling of the radar system. This reduced coupling degrades the depth of the signal penetration and the quality of the radargram. To combat these problems, before each line collection we removed surface clasts $>0.1$ from the 


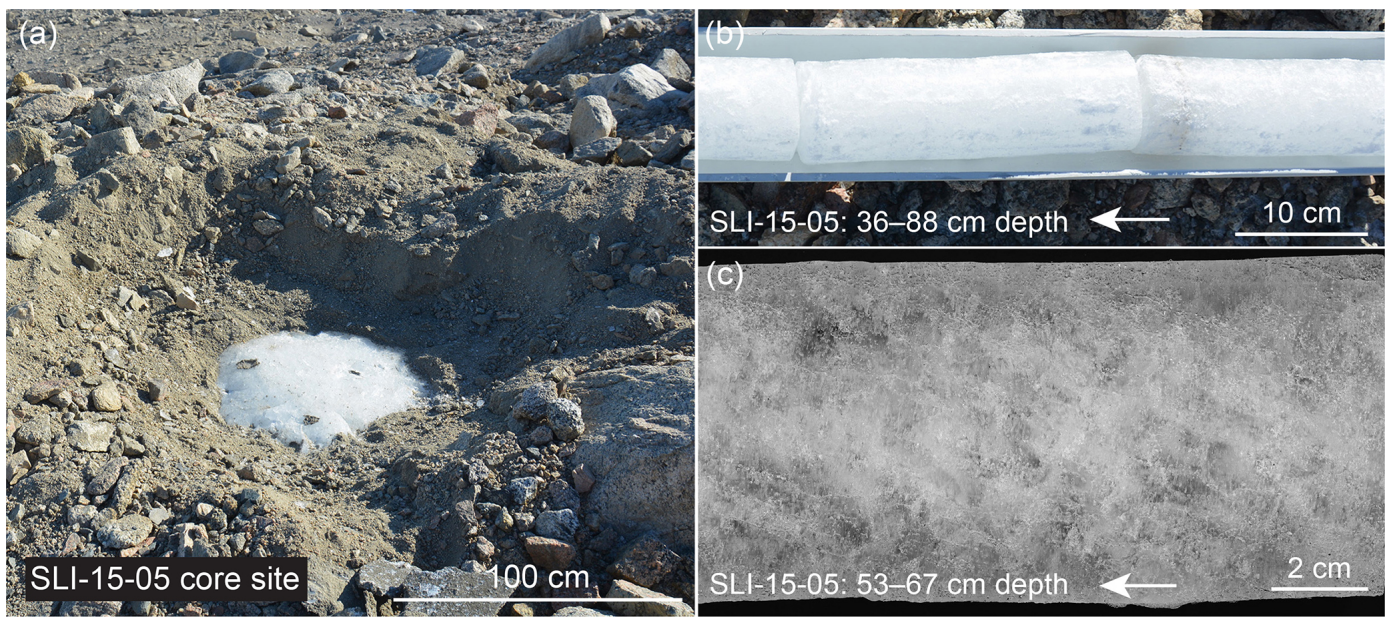

Figure 4. Buried ice core SLI-15-05. (a) Excavation of $\sim 30 \mathrm{~cm}$ of sand- and boulder-rich sediments above buried ice, exposing sharp contact between sediments and ice surface. (b) Buried ice core pictured in the field, $36-88 \mathrm{~cm}$ depth below ice surface; up-core is to the left (shown with arrow). (c) Buried ice core (53-67 cm depth) after being cut vertically at NICL. At this depth, buried ice contained many gas inclusions and no sediments.

GPR travel path and smoothed the surface sediment where possible. However, in places where clasts were frozen to the surface or too large to move, data quality was unavoidably degraded. We surveyed the start and end points of each GPR line with a handheld GPS receiver. We also marked the locations in the data files that corresponded to coring sites. Finally, after each line collection, we surveyed the slope along the line with a Brunton pocket transit and replaced all boulders.

\subsubsection{Data processing}

Initial data processing steps were (i) dewow to remove verylow-frequency components from the recorded data (Annan, 2005), (ii) distance normalization to correct for odometer errors (Shean and Marchant, 2010), and (iii) time-zero correction to the first peak of the direct arrival (Yelf and Yelf, 2007). We then filtered the data with a bandpass frequency filter (200 MHz: $50-100-400-800 \mathrm{MHz}$; $400 \mathrm{MHz}: 100-200$ $1000-2000 \mathrm{MHz}$ ), which was followed by background subtraction to enhance signal-to-noise ratio. Finally, we gained the data to enhance deeper reflections and cut the data to the useful time window. After these steps, analysis of diffraction hyperbolas provided radar-wave velocity estimates (Shean and Marchant, 2010). We used this velocity to apply topographic migration and topographic corrections to each line using surface profiles from the Brunton measurements. All data processing occurred with Reflex-2D processing software (Sandmeier, 2008).

\section{Results}

\subsection{Rock weathering trends}

The most abundant lithology on the rock glacier surface is granite (Figs. 5 and 6). In the upper half of the rock glacier, granitic clasts are primarily cobble- to boulder-size, subangular to very angular, and generally lacking in evidence of ventifaction (Figs. 5a, b and 6a). Occasional large boulders exhibit ventifact pitting, although these may be relict features inherited from in situ weathering while exposed along the cliff below Doran Glacier (e.g., Fig. 3b). In some areas, packed, angular pebbles are present between larger clasts (Fig. 5b). On the distal sector of the rock glacier, the character of surface clasts changes markedly. Granitic boulders are rounded and in some cases ventifaction and/or salt weathering has caused the development of surface pitting (Fig. 6b). The ground cover is grus, dominated by gravels and coarse sands (Figs. 5d, h and 6c). Where snowdrifts are protected by boulders, salt efflorescences and crusts can be found. Although cinder cone clasts are rare on the upper rock glacier, the lower rock glacier hosts patches of this material (Figs. 5i and $6 \mathrm{c}$ ), particularly in depressions that hold small ponds or appear to have held them in the past (evidenced by salt deposits). Pebble- to cobble-sized cinder cone clasts cover these depressions in a loose, poorly developed desert pavement. Occasional boulders of cinder cone material are also present on the lower rock glacier (Fig. $5 \mathrm{~g}$ ).

\subsection{Major ion concentrations}

Based on repeat aerial photography from 1956 to the present, all of the surface ponds on the rock glacier vary in size, generally reaching minima in the 1970s and 1980s. Five of the 
Table 1. Alpine glacier and rock glacier ice sample descriptions.

\begin{tabular}{|c|c|c|c|c|c|}
\hline Sample & $\begin{array}{l}\text { Latitude } \\
\qquad(\mathrm{S})\end{array}$ & $\begin{array}{r}\text { Longitude } \\
\qquad(\mathrm{E})\end{array}$ & $\begin{array}{l}\text { Elevation } \\
(\mathrm{m} \text { a.s.1. })^{1}\end{array}$ & Site description ${ }^{2}$ & Ice core/sample description ${ }^{3}$ \\
\hline SLI-15-01 & 77.71722 & 162.63182 & 740 & $\begin{array}{l}\text { Debris } \sim 10 \mathrm{~cm} \text { thick, fresh granitic } \\
\text { clasts, angular, few to no fines. }\end{array}$ & $\begin{array}{l}\text { Ice core. } 151 \mathrm{~cm} \text { long. } \\
\text { Clean ice, gas inclusions. }\end{array}$ \\
\hline SLI-15-04 & 77.71628 & 162.62518 & 670 & $\begin{array}{l}\text { Debris } \sim 20 \mathrm{~cm} \text { thick, fresh and } \\
\text { weathered granite, angular and } \\
\text { rounded clasts, sand-rich matrix. }\end{array}$ & $\begin{array}{l}\text { Ice core. } 156 \mathrm{~cm} \text { long. } \\
\text { Clean ice, gas inclusions. Debris } \\
\text { band at } 130-135 \mathrm{~cm} \text { depth. }\end{array}$ \\
\hline SLI-15-05 & 77.71537 & 162.61561 & 610 & $\begin{array}{l}\text { Debris } \sim 30 \mathrm{~cm} \text { thick, fresh and } \\
\text { weathered granite, rounded clasts, } \\
\text { sand-rich matrix. }\end{array}$ & $\begin{array}{l}\text { Ice core. } 228 \mathrm{~cm} \text { long. } \\
\text { Clean ice, gas inclusions. Debris } \\
\text { bands at } 12,70,170,190 \mathrm{~cm} \text { depth. }\end{array}$ \\
\hline SLI-15-08 & 77.71836 & 162.63216 & 780 & $\begin{array}{l}\text { Exposed ice at the boundary } \\
\text { between icefalls and buried ice. }\end{array}$ & $\begin{array}{l}\text { Hand sample. } 5 \mathrm{~cm} \text { depth } \\
\text { A: clean ice, gas inclusions. } \\
\mathrm{B} \text { and } \mathrm{C} \text { : clean ice, no gas inclusions. }\end{array}$ \\
\hline SLI-15-09 & 77.71760 & 162.63239 & 760 & $\begin{array}{l}\text { Exposed ice at the boundary } \\
\text { between icefalls and buried ice. }\end{array}$ & $\begin{array}{l}\text { Hand sample. } \\
\text { A: clean ice, gas inclusions. } \\
\text { B: clean ice, no gas inclusions. }\end{array}$ \\
\hline SLI-15-11 & 77.71759 & 162.62913 & 730 & $\begin{array}{l}\text { Debris } \sim 20 \mathrm{~cm} \text { thick, fresh and } \\
\text { weathered granitic clasts, sand } \\
\text { matrix. }\end{array}$ & $\begin{array}{l}\text { Hand sample from an exposed con- } \\
\text { traction crack. Clean ice. } 15 \mathrm{~cm} \\
\text { depth below ice-sediment boundary. }\end{array}$ \\
\hline SLI-15-12 & 77.71699 & 162.62979 & 720 & $\begin{array}{l}\text { Debris } \sim 10 \mathrm{~cm} \text { thick, fresh } \\
\text { angular granitic clasts, sands. }\end{array}$ & $\begin{array}{l}\text { Hand sample from buried ice } \\
\sim 60 \mathrm{~cm} \text { up-flow from pond SLI-15- } \\
02 \text {. Clean ice. } 5 \mathrm{~cm} \text { depth. }\end{array}$ \\
\hline SLI-15-13 & 77.71694 & 162.62891 & 720 & $\begin{array}{l}\text { Debris } \sim 5 \mathrm{~cm} \text { thick, fresh angular } \\
\text { granitic clasts, sands. }\end{array}$ & $\begin{array}{l}\text { Hand sample from buried ice } \sim 2 \mathrm{~m} \\
\text { down-flow from pond SLI-15-02. } \\
\text { Clean ice. } 5 \mathrm{~cm} \text { depth. }\end{array}$ \\
\hline SLI-15-14 & 77.71689 & 162.62882 & 720 & $\begin{array}{l}\text { Debris } \sim 10 \mathrm{~cm} \text { thick, fresh angular } \\
\text { granitic clasts, sands. }\end{array}$ & $\begin{array}{l}\text { Hand sample from buried ice } \sim 10 \mathrm{~m} \\
\text { down-flow from pond SLI-15-02. } \\
\text { Clean ice. } 5 \mathrm{~cm} \text { depth. }\end{array}$ \\
\hline SLI-15-15 & 77.71676 & 162.62831 & 700 & $\begin{array}{l}\text { Debris } \sim 5 \mathrm{~cm} \text { thick, fresh and } \\
\text { weathered angular granitic clasts, } \\
\text { sands. }\end{array}$ & $\begin{array}{l}\text { Hand sample from buried ice. Clean } \\
\text { ice. } 5 \mathrm{~cm} \text { depth. }\end{array}$ \\
\hline Doran Glacier & 77.71481 & 162.65637 & 880 & Left lateral terminus. & $\begin{array}{l}\text { Hand sample from glacier terminus. } \\
\text { Clean ice. }\end{array}$ \\
\hline Sollas Glacier & 77.71402 & 162.60377 & 530 & Right lateral terminus. & $\begin{array}{l}\text { Hand sample from glacier terminus. } \\
\text { Clean ice. }\end{array}$ \\
\hline
\end{tabular}

${ }^{1}$ Meters above sea level is denoted ma.s.l. ${ }^{2}$ Thickness and sedimentology of overlying debris. ${ }^{3}$ Length of ice core. Presence of gas inclusions and debris bands in buried ice. Depth of sampling.

ponds (KWL-15-03, SLI-15-02, SLI-15-06, SLI-15-17, and SLI-15-18) are persistent features in the aerial photographs, probably due to their relatively large sizes (Fig. 5c, f, g, and $h)$. The remaining sampled ponds are more ephemeral (KWL-15-01, KWL-15-02, SLI-15-10, SLI-15-16, and SLI15-19). Meltwater pond major ion concentrations range from those of freshwater to higher than those of seawater (Fig. 7 and Table 3). These results are compared to the average ion concentrations of seawater as described in Holland (1984). The highest major ion concentrations are found in the KWL-
15-02, KWL-15-03, and SLI-15-16 ponds, whereas the lowest concentrations are present in SLI-15-02, SLI-15-18, and SLI-15-19 (Fig. 8, Table S1 in the Supplement). Ratios of $\mathrm{Ca}^{2+}: \mathrm{Mg}^{2+}, \mathrm{Ca}^{2+}:\left(\mathrm{K}^{+}+\mathrm{Na}^{+}\right), \mathrm{Ca}^{2+}: \mathrm{Cl}^{-}$, and $\mathrm{SO}_{4}^{2-}: \mathrm{Cl}^{-}$decrease with increasing major ion concentrations (Fig. 7). The three ponds with the highest concentrations of $\mathrm{Cl}^{-}$also exhibit low ratios of $\left(\mathrm{K}^{+}+\mathrm{Na}^{+}\right): \mathrm{Cl}^{-}$relative to the other ponds. The concentrations of $\mathrm{Cl}^{-}$and $\mathrm{Na}^{+}$ in the most saline pond, KWL-15-03, are similar to that of seawater (Fig. 7a). Major ion concentrations are not corre- 
Table 2. Location and description of sampled meltwater ponds.

\begin{tabular}{lrrrrl}
\hline Lake ID $^{1}$ & $\begin{array}{r}\text { Maximum lake } \\
\text { dimension }(\mathrm{m})\end{array}$ & $\begin{array}{r}\text { Latitude } \\
(\mathrm{S})\end{array}$ & $\begin{array}{r}\text { Longitude } \\
(\mathrm{E})\end{array}$ & $\begin{array}{r}\text { Elevation } \\
(\mathrm{m} \text { a.s.1. })^{2}\end{array}$ & Ground surface character \\
\hline SLI-15-10 & 2 & 77.71750 & 162.63167 & 720 & Fresh sands to boulders \\
SLI-15-02 & 16 & 77.71697 & 162.62921 & 715 & Fresh and weathered boulders \\
KWL-15-01 & 4 & 77.71660 & 162.62654 & 650 & Weathered boulders \\
SLI-15-16 & 1 & 77.71623 & 162.62037 & 610 & Weathered boulders and grus \\
KWL-15-02 & 2 & 77.71606 & 162.61954 & 595 & Weathered boulders and grus \\
SLI-15-17 & 25 & 77.71611 & 162.61694 & 590 & Fresh boulders and grus \\
SLI-15-06 & 13 & 77.71512 & 162.61662 & 610 & Weathered boulders and grus \\
KWL-15-03 & 8 & 77.71559 & 162.61745 & 585 & Weathered boulders and grus \\
SLI-15-18 & 7 & 77.71514 & 162.61486 & 565 & Weathered boulders and grus \\
SLI-15-19 & 3 & 77.71510 & 162.61375 & 560 & Weathered boulders, grus and basalt cobbles \\
\hline
\end{tabular}

${ }^{1}$ Lakes listed from south to north (upper rock glacier to terminus). ${ }^{2}$ Meters above sea level.
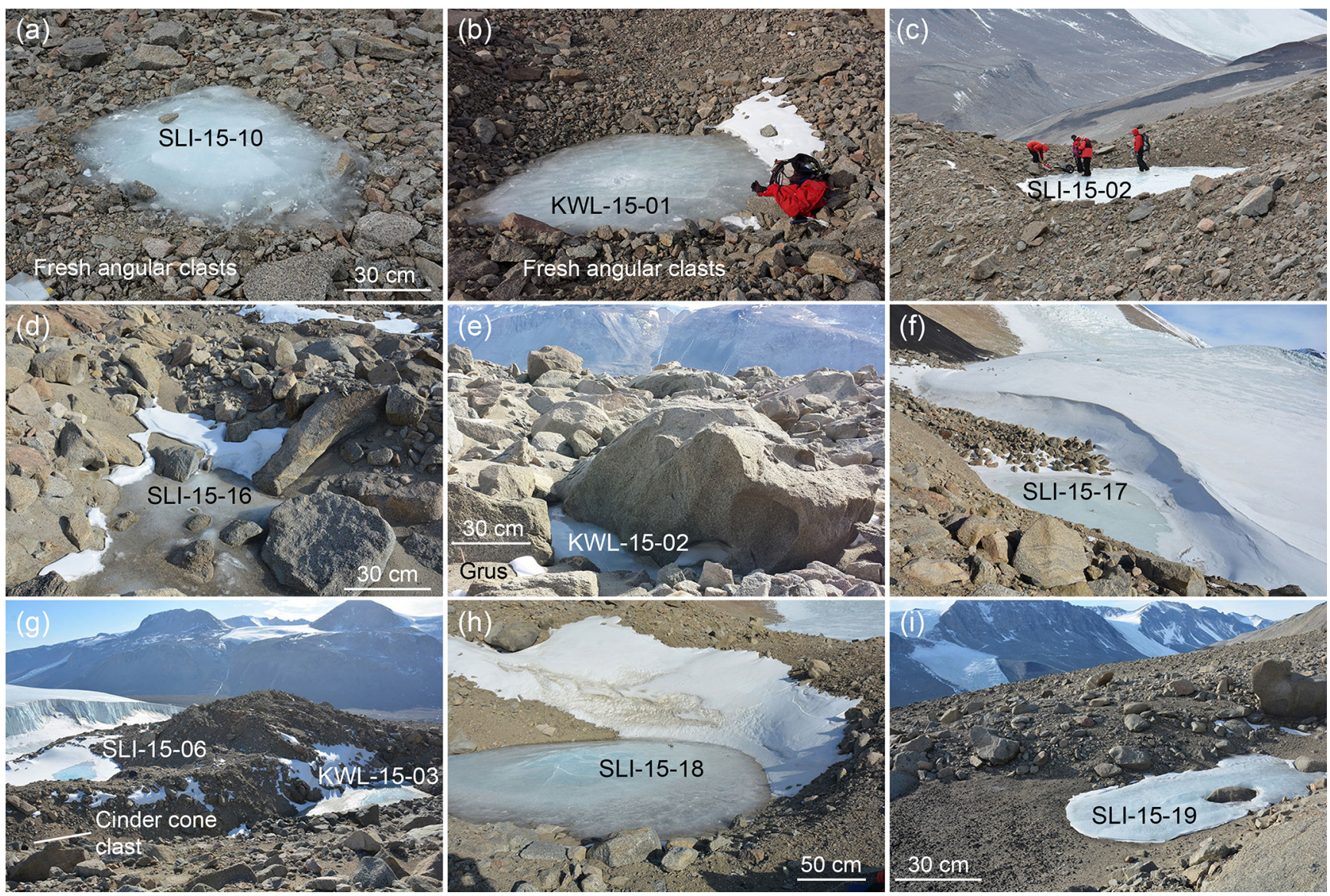

Figure 5. Field images of the 10 sampled meltwater ponds along a longitudinal transect down the rock glacier. (a) SLI-15-10 (b) KWL-1501, (c) SLI-15-02, (d) SLI-15-16, (e) KWL-15-02, (f) SLI-15-17, and (g) SLI-15-06 (on left) and KWL-15-03 (on right), (h) SLI-15-18, and (i) SLI-15-19. Pond SLI-15-17 occurs between the rock glacier margin and Sollas Glacier. Note the fresh appearance of granites surrounding KWL-15-01 and SLI-15-10 and the grussified ground surface surrounding KWL-15-02 and SLI-15-16 and SLI-15-18. 

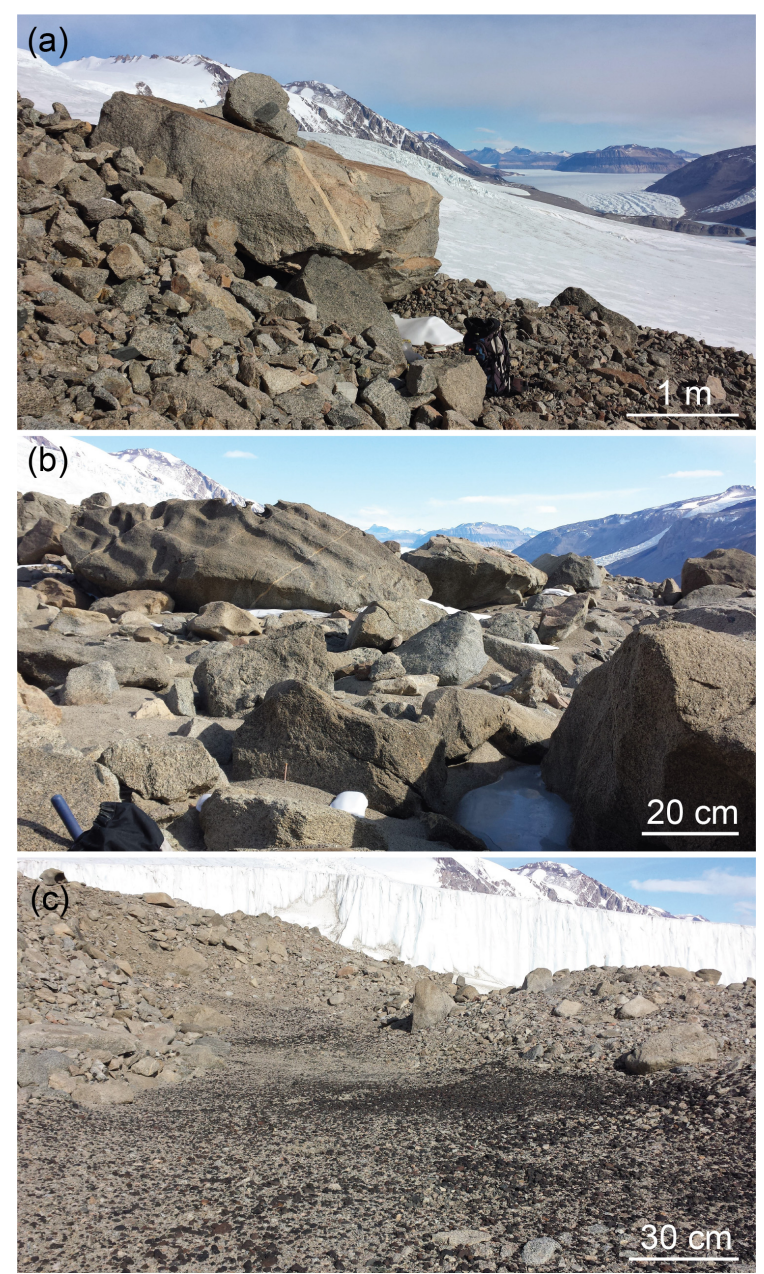

Figure 6. Surface lithology and weathering trend going down the rock glacier. (a) Upper rock glacier, showing fresh, angular granitic boulders and cobbles. (b) Central rock glacier, showing rounded and ventifacted granitic boulders and a granitic grus ground cover. (c) Lower rock glacier, showing smaller clast sizes and poorly developed desert pavement in a small depression with mixed granitic and basalt ground cover.

lated with pond size. The three most saline ponds are located in the lower rock glacier region; however, low-salinity ponds also occur in the lower rock glacier. Major ions from samples collected from the lower margins of Doran Glacier and Sollas Glacier show low total ion concentrations (Table 3).

\subsection{Stable isotopes}

Stable isotopic analyses were conducted on 54 samples from the buried ice ( 49 from the ice cores and five from the hand samples), 15 samples from surface ponds, five samples from the exposed icefalls, and four samples from Sollas and Doran glaciers (Table S2). Most of the ice samples fall near or slightly below the local meteoric water line (LMWL) defined by Gooseff et al. (2006) (Fig. 9). The local alpine

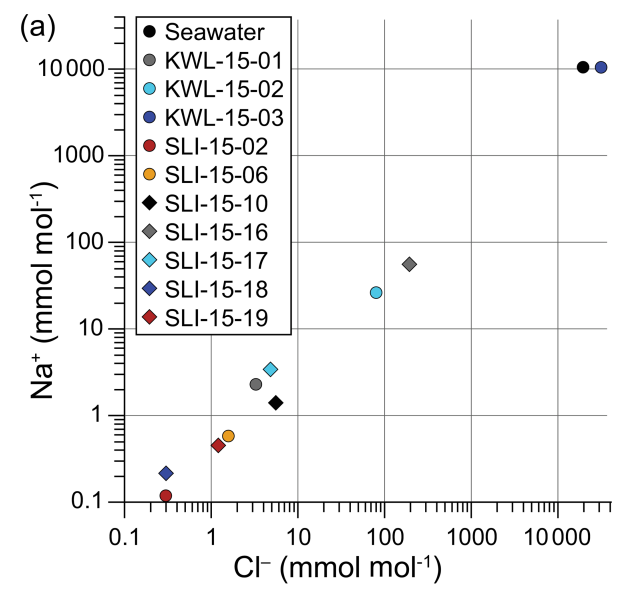

(b)

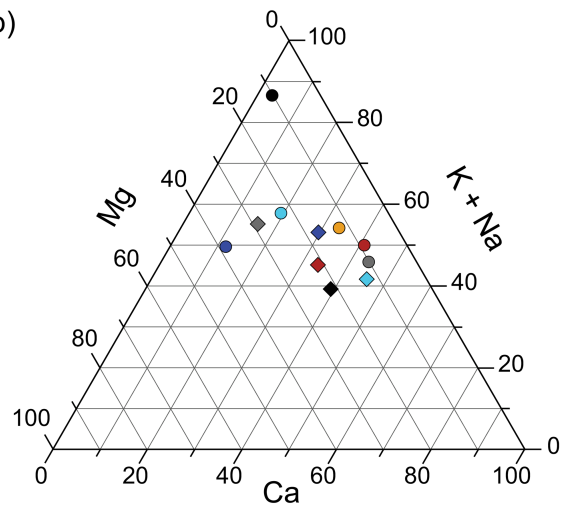

(c)

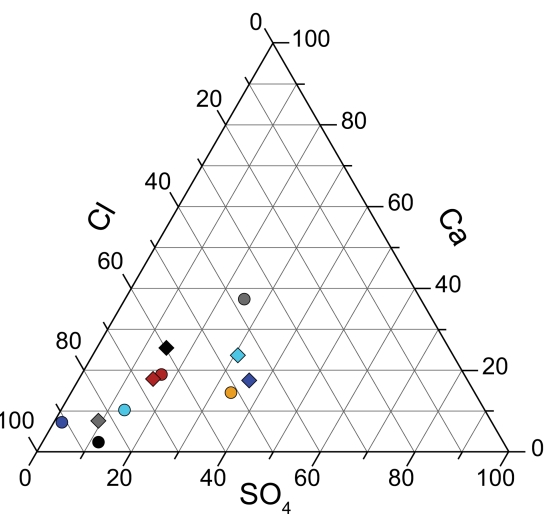

Figure 7. (a) Scatter plot of $\mathrm{Na}^{+}$vs. $\mathrm{Cl}^{-}$in 10 meltwater ponds. Ternary diagrams of (b) $\mathrm{Mg}^{2+}, \mathrm{Ca}^{2+}$, and $\mathrm{K}^{+}+\mathrm{Na}^{+}$and (c) $\mathrm{Cl}^{-}$, $\mathrm{SO}_{4}^{2-}$, and $\mathrm{Ca}^{2+}$ in meltwater ponds shown as percent by equivalent.

glaciers (Doran and Sollas) yield $\delta^{18} \mathrm{O}$ values from $-30 \%$ 。 and $-31 \%$, falling near the LMWL. Stable isotopic results from the three buried ice cores vary compared to the four glacier ice samples, but they are within the values observed from alpine glaciers in Taylor Valley (Gooseff et al., 2006). When plotted on a graph of $\delta^{18} \mathrm{O}$ vs. $\delta \mathrm{D}$, all 49 samples from the three buried ice cores (SLI-15-01, SLI-15-04, and SLI15-05) fall on a slope of 7.7 with an $R^{2}$ value of 0.99 . Samples from meltwater ponds display a large isotopic variance, 
Table 3. Major ion results.

\begin{tabular}{|c|c|c|c|c|c|c|c|c|}
\hline Sample ID ${ }^{1}$ & $\begin{array}{r}\mathrm{Ca} \\
(\mathrm{ppm})\end{array}$ & $\begin{array}{r}\mathrm{Cl} \\
(\mathrm{ppm})\end{array}$ & $\begin{array}{r}\mathrm{K} \\
(\mathrm{ppm})\end{array}$ & $\begin{array}{r}\mathrm{Mg} \\
(\mathrm{ppm})\end{array}$ & $\begin{array}{r}\mathrm{Na} \\
(\mathrm{ppm})\end{array}$ & $\begin{array}{r}\mathrm{NO}_{3} \\
(\mathrm{ppm})\end{array}$ & $\begin{array}{r}\mathrm{SO}_{4} \\
(\mathrm{ppm})\end{array}$ & $\begin{array}{l}\text { Total major } \\
\text { ions (ppm) }\end{array}$ \\
\hline \multicolumn{9}{|l|}{ Buried ice } \\
\hline \multicolumn{9}{|l|}{ SLI-15-01 } \\
\hline $0 \mathrm{~cm}$ & 3.232 & 15.883 & 0.461 & 1.581 & 6.324 & 0.567 & 3.918 & 32.921 \\
\hline $75 \mathrm{~cm}$ & 3.665 & 30.808 & 0.429 & 2.908 & 7.897 & 1.074 & 4.894 & 52.346 \\
\hline $114 \mathrm{~cm}$ & 2.357 & 30.654 & 1.643 & 3.725 & 8.427 & 1.156 & 1.607 & 50.586 \\
\hline $143 \mathrm{~cm}$ & 7.285 & 47.558 & 1.471 & 7.140 & 11.066 & 1.994 & 5.903 & 84.277 \\
\hline \multicolumn{9}{|l|}{ SLI-15-04 } \\
\hline $15 \mathrm{~cm}$ & 4.151 & 7.673 & 0.624 & 0.609 & 4.187 & 0.229 & 7.271 & 26.068 \\
\hline $65 \mathrm{~cm}$ & 5.044 & 11.027 & 0.427 & 1.123 & 5.595 & 0.284 & 13.205 & 37.216 \\
\hline $149 \mathrm{~cm}$ & 8.043 & 21.213 & 1.068 & 3.050 & 6.856 & 0.979 & 17.487 & 61.489 \\
\hline \multicolumn{9}{|l|}{ SLI-15-05 } \\
\hline $15 \mathrm{~cm}$ & 0.651 & 9.592 & & 0.140 & 5.810 & 0.499 & 1.044 & 18.150 \\
\hline $137 \mathrm{~cm}$ & 0.874 & 12.582 & 0.430 & 0.170 & 7.395 & 0.483 & 1.251 & 23.691 \\
\hline $210 \mathrm{~cm}$ & 0.907 & 14.379 & & 0.219 & 8.109 & 0.459 & 1.514 & 25.951 \\
\hline SLI-15-08A & 0.608 & 3.183 & 0.564 & 0.479 & 2.012 & 0.206 & 0.503 & 9.727 \\
\hline SLI-15-08B & 0.622 & 1.876 & & 0.439 & 1.067 & 0.227 & 0.373 & 6.293 \\
\hline SLI-15-08C & 0.284 & 1.951 & & 0.200 & 1.205 & 0.163 & 0.230 & 4.754 \\
\hline SLI-15-09A & 2.145 & 13.737 & 0.390 & 1.321 & 5.475 & 0.407 & 2.181 & 26.255 \\
\hline SLI-15-09B & 0.452 & 5.756 & 0.326 & 1.229 & 1.451 & 0.628 & 0.378 & 10.842 \\
\hline SLI-15-11 & 6.109 & 9.607 & 0.650 & 1.067 & 5.764 & 0.481 & 5.772 & 33.950 \\
\hline SLI-15-12 & 5.074 & 9.656 & 1.029 & 2.505 & 5.363 & 0.866 & 3.222 & 29.463 \\
\hline SLI-15-13 & 4.701 & 17.819 & 0.435 & 2.406 & 5.499 & 1.078 & 5.607 & 38.311 \\
\hline SLI-15-14 & 2.627 & 5.147 & 0.444 & 0.743 & 3.391 & 0.333 & 1.756 & 17.221 \\
\hline SLI-15-15 & 2.659 & 17.882 & 0.751 & 2.426 & 3.843 & 1.494 & 3.383 & 34.652 \\
\hline \multicolumn{9}{|l|}{ Ponds } \\
\hline \multicolumn{9}{|l|}{ SLI-15-02 } \\
\hline $0 \mathrm{~cm}$ & 0.100 & 0.320 & & 0.023 & 0.121 & 0.136 & 0.085 & 1.043 \\
\hline $21 \mathrm{~cm}$ & 0.166 & 0.105 & & 0.020 & 0.066 & 0.350 & 0.057 & 1.071 \\
\hline $53 \mathrm{~cm}$ & 0.081 & 0.061 & & 0.011 & 0.068 & 0.051 & 0.039 & 0.530 \\
\hline $74 \mathrm{~cm}$ & 0.105 & 0.375 & & 0.021 & 0.109 & 0.154 & 0.117 & 1.110 \\
\hline \multicolumn{9}{|l|}{ SLI-15-06 } \\
\hline $0 \mathrm{~cm}$ & 0.431 & 1.569 & & 0.153 & 0.687 & 0.285 & 0.973 & 4.335 \\
\hline $10 \mathrm{~cm}$ & 0.270 & 0.806 & & 0.083 & 0.391 & 0.248 & 0.491 & 2.618 \\
\hline KWL-15-01 & 3.139 & 3.260 & 0.943 & 0.721 & 2.334 & 0.238 & 2.186 & 14.387 \\
\hline KWL-15-02 & 10.226 & 80.281 & 3.960 & 11.920 & 26.572 & 1.903 & 14.030 & 150.938 \\
\hline KWL-15-03 & 2675.000 & 31378.090 & 704.412 & 8826.545 & 10673.190 & 209.167 & 465.176 & 54979.690 \\
\hline SLI-15-10 & 2.354 & 5.571 & 0.352 & 1.291 & 2.005 & 0.350 & 1.426 & 13.769 \\
\hline SLI-15-16 & 17.600 & 193.816 & 5.295 & 32.458 & 57.004 & 4.166 & 23.134 & 334.064 \\
\hline SLI-15-17 & 2.459 & 4.833 & 0.977 & 1.345 & 3.449 & 0.329 & 3.236 & 17.198 \\
\hline SLI-15-18 & 0.122 & 0.301 & & 0.071 & 0.219 & 0.123 & 0.235 & 1.546 \\
\hline SLI-15-19 & 0.338 & 1.217 & & 0.213 & 0.456 & 0.272 & 0.281 & 3.791 \\
\hline \multicolumn{9}{|l|}{ Glaciers } \\
\hline Doran Gl. & 0.422 & 2.09 & & 0.590 & 0.762 & 0.348 & 0.48 & 5.898 \\
\hline Sollas Gl. & 1.564 & 1.93 & 0.525 & 0.913 & 1.138 & 0.340 & 8.747 & 18.059 \\
\hline
\end{tabular}

${ }^{1}$ Depth below ice surface is listed in centimeters for ice cores (only SLI-15-01, SLI-15-02, SLI-15-04, SLI-15-05, and SLI-15-06). All other samples were gathered from 0 to $10 \mathrm{~cm}$ depth in buried ice or pond. Glacier samples are from margins. Where concentrations fall below detection limits, cells are left blank. Reported detection limits (ppm) were $\mathrm{Ca}(0.027), \mathrm{Cl}(0.02), \mathrm{K}(0.134), \mathrm{Mg}(0.042), \mathrm{Na}(0.027), \mathrm{NO}_{3}(0.05)$, and $\mathrm{SO}_{4}(0.02)$. Total major ions are calculated as the sum of all 14 measured species (see Supplement). 
with $\delta^{18} \mathrm{O}$ values ranging from $-31 \%$ o to $-22 \%$. The pond samples fall below the LMWL on a slope of 6.0, with an $R^{2}$ value of 0.94 .

\subsection{GPR}

Mean radar-wave velocity derived from analyses of diffraction hyperbolas throughout the data sets was approximately $0.15-0.16 \mathrm{~m} \mathrm{~ns}^{-1}$. Migrations using this velocity successfully collapsed diffractions without introducing data artifacts (Figs. 10 and 11). However, the overlying debris layer of typically less than $0.2 \mathrm{~m}$ thickness likely has a lower velocity. This layered velocity structure is a source of error in our processing and subsequent analysis. In spite of the problems encountered with ground coupling due to surface roughness, effective depth of penetration after migration was $10-20 \mathrm{~m}$ in the $400 \mathrm{MHz}$ data and $>15 \mathrm{~m}$ in the $200 \mathrm{MHz}$ data. The processed data exhibited coherent reflection events within $0.1-0.2 \mathrm{~m}$ of the surface and below (Fig. 10). These reflection events generally appear as flat-lying and dipping reflectors separating portions of the radargrams with comparatively low signal content (Fig. 10). Two selected longitudinal lines are shown in Fig. 11; all five longitudinal $400 \mathrm{MHz}$ lines are provided in the Supplement.

\section{Discussion}

\subsection{Stable isotopes and buried ice origin}

Stable isotopic data from the buried ice, pond, and alpine glaciers support a glacial origin for the rock glacier ice, with some meltwater infiltration and reworking. Doran and Sollas glaciers are isotopically similar and follow the general trend of Taylor Valley (more depleted isotopic values for inland glaciers compared to glaciers near the coast) (Gooseff et al., 2006). The modern glacier ice also falls around the median isotopic values for all samples from the rock glacier region. The pond ice is isotopically heavy with respect to oxygen and plots well below the LMWL, indicating that it has experienced greater isotopic fractionation due to evaporation compared to the buried ice and glacier ice.

At the boundary between the icefalls and the debriscovered ice, the sampled exposed ice (SLI-15-08 and SLI15-09) is a mixture of bubble-rich ice clasts in a clear-ice matrix (Fig. 8). At these locations, the bubble-rich ice samples fall on the LMWL isotopically, whereas samples from the clear-ice matrices fall below (Fig. 9). The bubble-rich samples are likely preserved glacial ice. This interpretation is supported by the presence of fine spherical gas inclusions and snow accumulation stratigraphy. Conversely, the clearice matrices appear to be refrozen meltwater that has experienced minor evaporation fractionation.

\subsection{Rock glacier subsurface structure}

Ground-penetrating radar along the rock glacier (Fig. 2) shows clear subsurface structure and clean ice (selected radargrams shown in Figs. 10 and 11). As verified via field excavations, a contact between clean buried ice and overlying sediments is commonly encountered at $<30 \mathrm{~cm}$ depth. This interface between overlying unconsolidated sediments and the underlying clean ice containing scattered debris corresponds with the shallowest reflection event in the radar data. Where the longitudinal GPR transect crossed ice-coring locations, we were able to correlate low GPR signal, or radar transparent regions (Brown et al., 2009), in the radargrams to the clean ice observed in the cores (Fig. 11). In the west-east (transverse) line across the boundary between the exposed icefalls and the buried ice (Figs. 2 and 10), we observe the same characteristically low-signal areas in the radargram interrupted by a prominent internal reflection event. This internal reflection event highlights the signal quality and radar transparency of the materials above and below it. Additionally, the mean radar-wave velocity throughout our data set, obtained from diffraction pattern analyses, is within $6 \%$ of that of clean, freshwater ice $\left(0.167 \mathrm{~m} \mathrm{~ns}^{-1}\right)$. Finally, the depth of penetration for both frequencies employed is triple or greater than that normally seen when using these frequencies for rock or soil materials. This increased penetration is likely due to the low attenuation typically exhibited by radar waves traveling through cold ice (Arcone et al., 1995). Combined, these observations support our GPR-derived interpretation that the rock glacier is primarily ice-cored. Near the boundary between the exposed icefalls and the debriscovered ice, ice thickness is $>6 \mathrm{~m}$ (Fig. 10), and near the toe of the rock glacier ice thickness is $>10 \mathrm{~m}$ in some locations (Fig. 11).

The prominent reflection events in the survey across the exposed icefalls are interpreted to be internal debris layers. On the transverse line (Fig. 10), the primary reflection event from the surface debris layer extends into the exposed icefalls and then dips upward toward the surface of the bounding icecored ridge (on the eastern rock glacier margin). The reflector maintains coherency particularly in the first meter of descent away from the debris-covered ice (line positions from 20 to $30 \mathrm{~m}$ ), supporting our interpretation that it represents continuous internal debris. Thereafter, the layer maintains a consistent polarity indicative of the ice-debris-ice interface, although it becomes less coherent. At the $\sim 50 \mathrm{~m}$ position along the line, another internal reflection event separates from the prominent debris layer and follows a similar (though less steep) dip, joining the primary upward-dipping debris layer at the $\sim 105 \mathrm{~m}$ line position. Below these prominent debris layers, more interpreted clean ice extends to at least the depth of signal penetration. Our observations also provide clear supporting evidence for a supraglacial source of entrained debris that then travels englacially with rock glacier flow. This pattern of repetitive internal and upward-dipping 


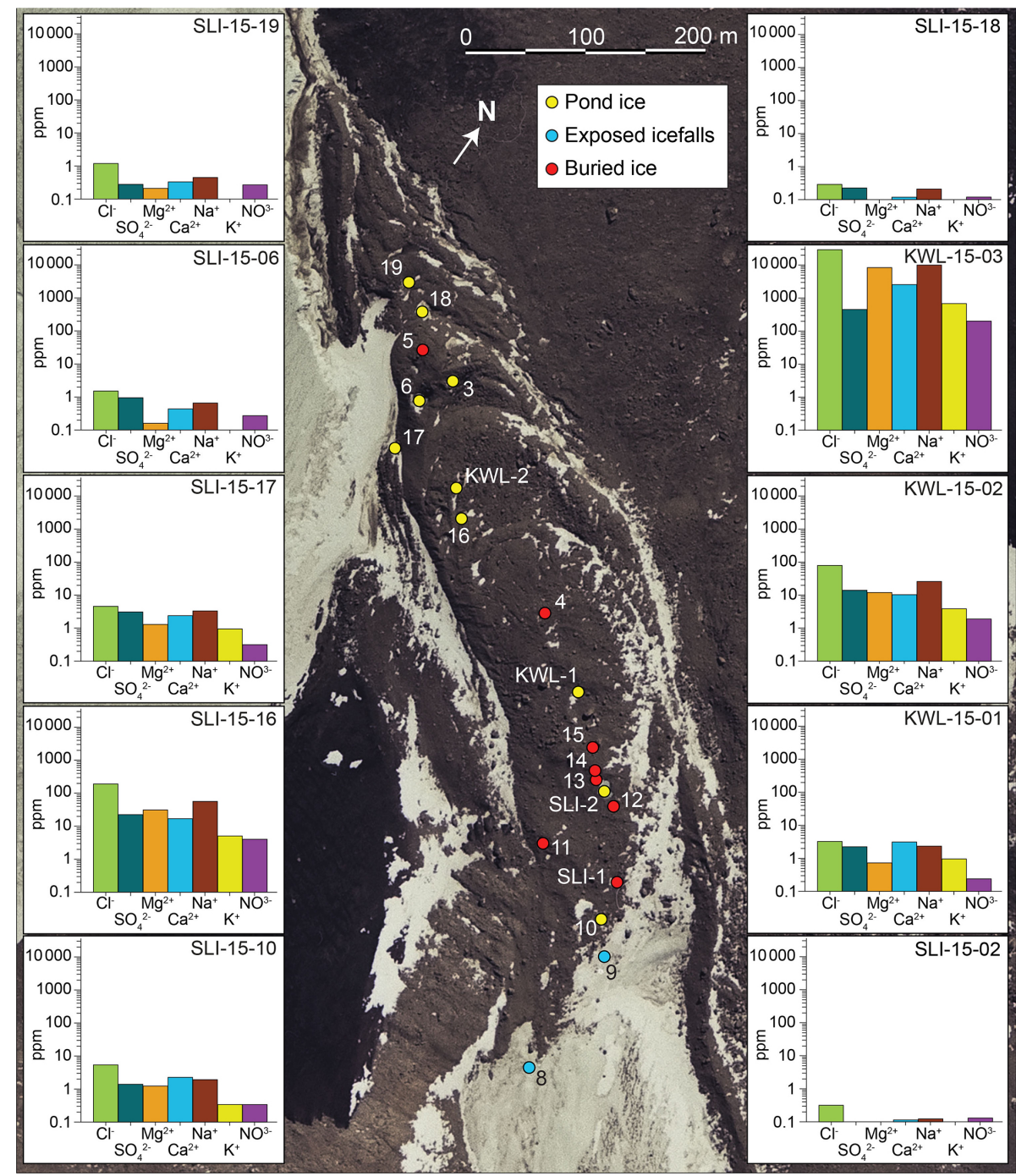

Figure 8. Aerial photo of the rock glacier with pond samples and buried ice samples. Cinder cone talus and the eastern margin of Sollas Glacier are both visible to the west of the rock glacier. Bar charts show major ion concentrations from 10 meltwater ponds (shown with yellow circles). All samples are labeled with their numbers only, except where the same sample numbers correspond to different samples (SLI-15-01 and SLI-15-02 vs. KWL-15-01 and KWL-15-02), labeled as SLI- and KWL-. Public domain aerial photograph from U.S. Geological Survey, TMA3084-V0132 taken in 1993.

reflectors is evocative of previous work on the Dry Valley debris-covered glaciers Mullins and Friedmann (Mackay et al., 2014).

Throughout the longitudinal transect, we observed similar internal reflectors and patterns, interpreted to be clean subsurface ice with entrained debris bands (arrows, Fig. 11). Dominant dip of englacial debris layers is toward the toe of the rock glacier, corresponding to our interpretation of passive entrainment and subsequent redistribution of supraglacial debris. Where the longitudinal transect crosses surface ponds on the rock glacier, internal reflectors extend from the near surface $(\sim 0.1 \mathrm{~m})$ downward to form the base of the pond and presumably the interface between the melt ice and underlying bubble-rich glacier-derived ice (Shean and Marchant, 2010). We were unable to core below the ponds' basal layers. In pond SLI-15-06 (Fig. 11b), two distinct debris layers bounding the pond run parallel to each other, while a third dips upward more abruptly. The lack of signal in the rest of the radargram near this location indicates the presence of clean ice below the surface debris layer, with a few areas having some entrained debris. Down the rock glacier from the pond, it appears that this basal pond debris layer becomes further entrained and migrates down-flow.

The GPR data support multiple advances and retreats of the source for the rock glacier ice, Doran Glacier. In the transverse line (Fig. 10), the exposed ice at line positions from 30 to $115 \mathrm{~m}$ records the modern advance of Doran Glacier and the associated calving of ice from its lateral mar- 


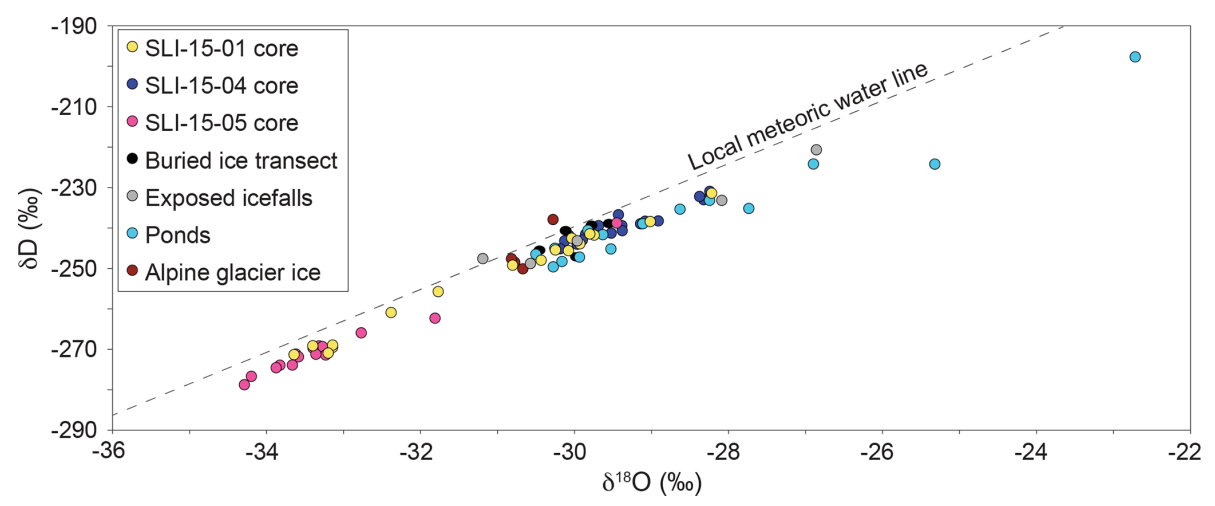

Figure 9. Plot of $\delta^{18} \mathrm{O}$ vs. $\delta \mathrm{D}$ of 59 samples from the rock glacier. Cores 01,04 , and 05 were gathered from buried ice along a longitudinal transect down the central flow line of the rock glacier. Buried ice transect refers to additional hand samples KWL-15-11 to KWL-15-15 (see Fig. 8 for locations). Exposed icefalls were five samples from two locations (SLI-15-08 and SLI-15-09; Fig. 8). Samples were also gathered from seven ponds along the rock glacier surface (SLI-15-02, SLI-15-06, SLI-15-10, SLI-15-16, SLI-15-17, SLI-15-18, and SLI-15-19; Fig. 8) and two local alpine glaciers, Sollas and Doran. The local meteoric water line is from Gooseff et al. (2006).

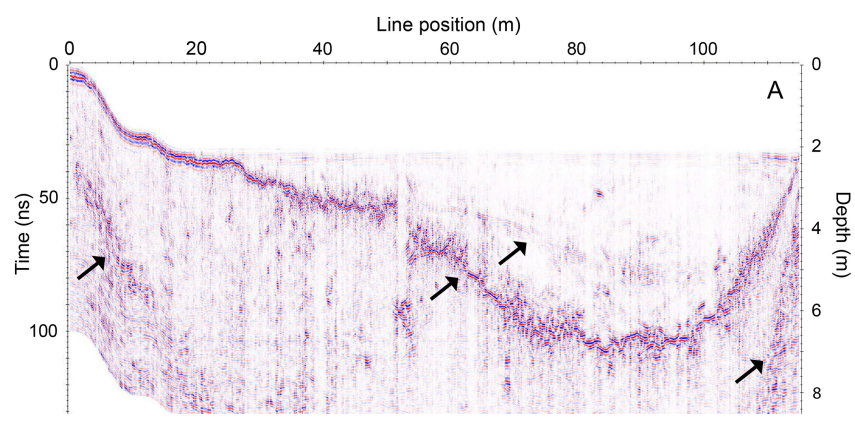

Figure 10. Processed $400 \mathrm{MHz}$ ground-penetrating radar data for the transverse line (west to east) from the debris-covered rock glacier across the icefalls fed by Doran Glacier and ending at the east-lateral ice-cored ridge. Image after migration and topographic correction using a constant velocity of $0.16 \mathrm{~m} \mathrm{~ns}^{-1}$. The prominent internal reflection event starts as a near-surface reflection event at the beginning of the profile. Interpreted as an interface between surface debris and internal ice, the debris layer dips below the exposed ice at the $\sim 20 \mathrm{~m}$ line position before emerging at the ice-cored ridge (right side of profile). Arrows point to reflection events interpreted to be internal debris layers, likely recording periods of retreat of the source glacier.

gin. The prominent subsurface debris layers below the modern ice likely record previous period(s) of Doran Glacier retreat. During glacier retreat the rock glacier loses its source for ice, allowing a debris layer to accumulate at the rock glacier surface via ablation and rockfall. Below the prominent debris layer, the low-signal zone (interpreted to be more ice) likely records older advance(s) of Doran Glacier. Based on this interpretation, the transverse radargram records at least two recent advances of Doran Glacier (Fig. 10).

\subsection{Surface trends in relative age}

The accumulation of major ions in meltwater ponds should be driven by two primary processes: snowfall and chemical weathering (Sun et al., 2015). Snowfall in the Dry Valleys contains aerosols of marine origin, which are a significant source of $\mathrm{Cl}^{-}$and $\mathrm{NO}_{3}^{-}$to the regional soils (Witherow et al., 2006). Although the surface sediments of the rock glacier do experience summer thaw, the thaw season is generally short in this region $\left(\sim 34\right.$ degree days $\mathrm{yr}^{-1}$ along Lake Bonney in the valley floor (Doran et al., 2002). Compared to the coastal Dry Valleys, weathering is therefore less of a contributor to soil and meltwater major ions (Bao et al., 2008).

Based on the shape and position of meltwater pond KWL15-02, it evolved from a snowbank (Fig. 5e), which supports the interpretation that snowfall is a dominant contributor to the ponds. Some authors have reported increasing concentrations of the more soluble binary ions in downslope meltwater ponds due to the freeze-thaw-driven migration of those ions from upslope ponds (Healy et al., 2006; Lyons et al., 2012). However, we see a relative increase in the less soluble $\mathrm{Mg}^{2+}$ in the lower meltwater ponds (Figs. $7 \mathrm{~b}$ and 8), suggesting that the freeze-thaw process does not control the major ion concentration trend. Additionally, the hummocky, irregular surface topography of the rock glacier likely restricts connectivity between the upper and lower rock glacier (Figs. 2 and 8).

Our major ion concentrations and cation ratios are dissimilar to those reported in meltwater ponds surrounding Marr Glacier, $\sim 3 \mathrm{~km}$ northeast of the rock glacier (Fig. 1) (Lyons et al., 2012). This is likely due to the direct input of glacial meltwater to the Marr ponds, which possesses low concentrations of major ions as well as ratios driven strongly by snowfall. The rock glacier ponds are more isolated and subject to evaporative concentration of ions. We suggest that the ponds in the upper rock glacier (SLI-15-02, SLI-15-10 and 

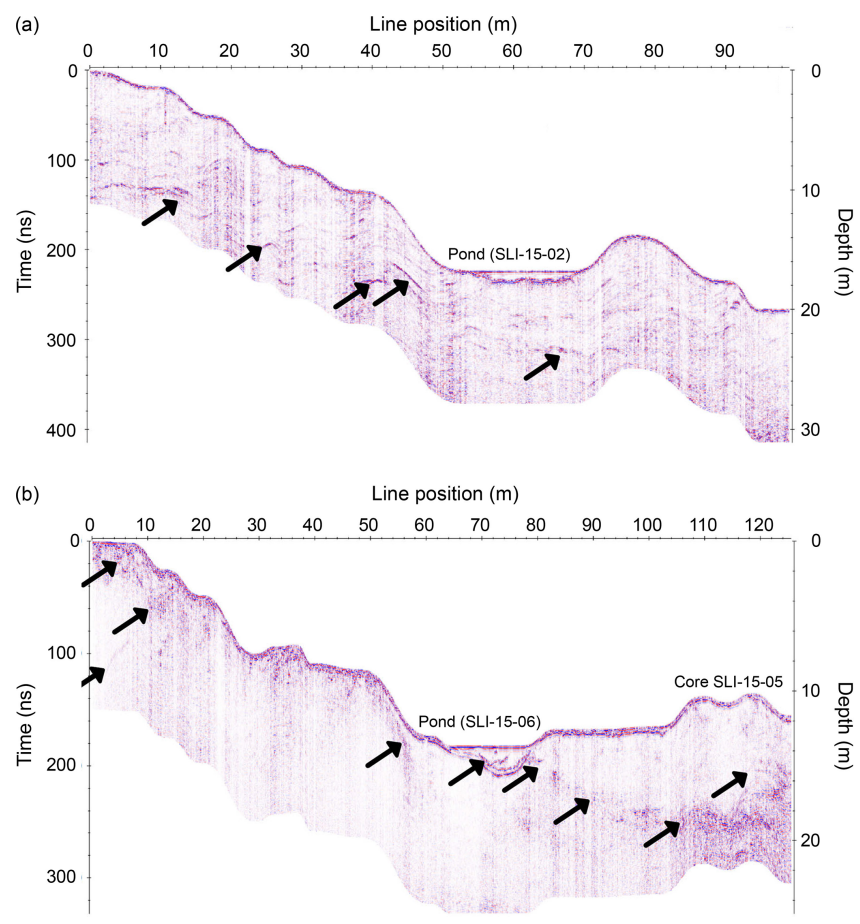

Figure 11. Processed $400 \mathrm{MHz}$ ground-penetrating radar data from the transect down the rock glacier. (a) Mid-rock glacier line showing interpreted internal debris and a mid-rock glacier pond $(\sim 50$ $70 \mathrm{~m}$; site of ice core samples SLI-15-02 and SLI-15-03). (b) Part of the transect crossing the frozen pond (sample sites SLI-15-06 and SLI-15-07) near the lowest buried ice core site (at $110 \mathrm{~m}$; SLI-1505). Arrows point to reflection events interpreted to correlate with internal debris layers.

KWL-15-01) have low total ion concentrations due to their relative youth and potential meltwater contribution from the Doran Glacier icefalls (Fig. 8). Ponds SLI-15-18 and SLI-1519 contain some of the lowest ion concentrations we measured but occur near the rock glacier toe where the landform is older. However, at this location, the surface morphology is distinct from the rest of the rock glacier: (1) the hummocks are lower relief and (2) the arcuate transverse ridges are incised by fluvial channels that are oriented longitudinally to rock glacier flow. We were also unable to find clean subsurface ice in this lowest section of the rock glacier (based on five field excavations). Pond SLI-15-19 is a small, ephemeral feature (Fig. 5i). Pond SLI-15-18 is larger and long-lived but in a shallow depression with a northern bounding bank that was $<50 \mathrm{~cm}$ above the modern pond surface. This configuration, along with the evidence for fluvial channeling, might allow pond water to flow out during high stands, thus limiting long-term concentration of ions in the depressions. Conversely, pond KWL-15-03, which exhibits significantly higher ion concentrations than any of the other analyzed ponds, sits in one of the deepest depressions on the entire rock glacier, 2-5 m deep on all sides. At this location, the rock glacier contains $>10 \mathrm{~m}$ of clean buried ice
(Fig. 11b), but sediment cover over the buried ice is $>30 \mathrm{~cm}$ thick (Fig. 4a), allowing for little to no melting of the buried ice as a source for pond water.

High salinity of surface ponds, such as KWL-15-03, implies a long surface exposure history for the lower rock glacier. Concentrations of $\mathrm{Cl}^{-}$are likely controlled by aerosol inputs from snow and ice melt, as well as dissolution and subsequent aeolian and near-surface groundwater transport from nearby sediments, with a small contribution from weathering of cinder cone clasts (Keys and Williams, 1981; Witherow et al., 2006; Toner et al., 2013). If the measured $\mathrm{Cl}^{-}$concentration of KWL-15-03 is representative of the pond in general and the $\mathrm{Cl}^{-}$was sourced solely from aerosol deposition across the entire $\sim 600 \mathrm{~m}^{2}$ depression that surrounds the $\sim 12 \mathrm{~m}^{2}$ pond, then the accumulation of $\mathrm{Cl}^{-}$to the pond would take longer than the Holocene ( $\sim 40 \mathrm{kyr}$ ). This estimate is based on the modern $\mathrm{Cl}^{-}$flux of $\sim 150 \mu \mathrm{mol} \mathrm{m}^{-2} \mathrm{yr}^{-1}$ to four snow pits on Sollas Glacier (Witherow et al., 2006) and the measured $\mathrm{Cl}^{-}$concentration of $\sim 31400 \mathrm{ppm}$ applied to the entire volume $(\sim 4000 \mathrm{~L})$ of the pond (Table S1). This calculated age would be an overestimation if (a) the surface ice has a higher salinity than the lower pond ice, (b) there is a significant in situ weathering source of $\mathrm{Cl}^{-}$, and/or (c) wind-blown snow and wind-blown ions preferentially accumulate in the depression. Conversely, the calculated age would be an underestimation if (a) the surface ice has a lower salinity than the bottom ice due to topdown freezing and brine expulsion at the bottom of the pond, (b) there is aeolian removal of ions from the pond depression during desiccation events, and/or (c) some $\mathrm{Cl}^{-}$is retained in surrounding sediments rather than being transported to the pond. Additionally, long-term variations in snowfall, the size of the depression, and fluvial/subsurface water flow would affect $\mathrm{Cl}^{-}$transport to the pond. Due to all of these factors and uncertainties, an absolute surface age for the lower rock glacier cannot be calculated based simply on the pond salinity. The antiquity of the lower rock glacier is evidenced by the grussification of granites, the rounding of surface clasts, the accumulation of relatively thick $(>30 \mathrm{~cm})$ sediment cover over the buried ice, and the GPR record of multiple advances and retreats of the source glacier. When coupled with this relative chronology of surface weathering and buried ice accumulation and flow, the high $\mathrm{Cl}^{-}$concentrations measured in KWL-15-03 might suggest a pre-Holocene age for the lower rock glacier.

\subsection{Implications for McMurdo Dry Valleys glaciers}

Meltwater pond salinity and observations of surface weathering suggest that portions of the rock glacier could have survived since before the Holocene. Distinct weathering regimes along the rock glacier surface support an episodic nature of rock glacier development, as do the dispersal of englacial debris and the arcuate surface ridges. If the rock glacier surface near pond KWL-15-03 is pre-Holocene, it is 
possible that the rock glacier preserves evidence of advances from older interglacial intervals. Regardless of the exact age, the rock glacier preserves, in a single feature, a record of multiple alpine glacier advances for which the direct geomorphic evidence (such as moraines beyond the toe of Doran Glacier) is unavailable.

Taylor Valley glacial geomorphology shows evidence for advances of both outlet and alpine glaciers during MIS 5, 7, 9, and 11 (Higgins et al., 2000; Swanger et al., 2017). Even though Dry Valley glaciers appear to have advanced during the Holocene relative to the Last Glacial Maximum, the timing and details of Holocene advance dynamics are unresolved (Hall and Denton, 2000). Therefore, if rock glaciers can preserve a record of Holocene (or older) glacier advance and retreat, these landforms can be used to constrain regional glacial fluctuations, especially where moraines are absent. In addition to the stated implications for the McMurdo Dry Valleys, our results have wider significance. Buried ice and rock glaciers are common throughout the ice-free regions of Antarctica (Fukui et al., 2008; Hassinger and Mayewski, 1983; Bibby et al., 2016). Based on our results, it is likely that many ice-cored rock glaciers elsewhere in Antarctica record past glacial fluctuations, and can therefore be used to study climatic history during the Holocene and Pleistocene.

\section{Conclusions}

We use a combination of ground-penetrating radar, field observations, and stable isotope and major ion analyses to characterize a rock glacier fed by the Doran Glacier icefalls in Taylor Valley. The rock glacier subsurface is primarily clean ice that is at least $10 \mathrm{~m}$ thick, with englacial debris bands that in places outcrop at the surface. Stable isotope values that are consistent with those of glacial ice, along with the presence of spherical gas inclusions, confirm that the buried ice within the rock glacier is glacial in origin. Surface weathering trends including the development of ventifacts, grus, and minor desert pavement on the lower rock glacier suggest that the rock glacier toe is significantly older than the upper rock glacier. Major ion concentrations in meltwater ponds are variable and consistent with aerosol deposition acting as the primary source for major ions. Our data support episodic advances of the rock glacier, which likely record Doran Glacier margin fluctuations during the late Pleistocene and Holocene. This demonstrates the potential utility of Antarctic rock glaciers in preserving glacial behavior despite nondeposition of moraines and/or the destruction of older glacial landforms by younger advances.
Data availability. All geochemical data are provided in the Supplement.

Supplement. The supplement related to this article is available online at: https://doi.org/10.5194/tc-14-1-2020-supplement.

Author contributions. All authors participated in field observations, GPR surveying, and ice core collection. KMS organized and led the field campaign. KW and KMS collected soil and ice hand samples. EB directed GPR surveying and performed all GPR data processing. KW processed samples for major ion analyses. KW and KMS processed samples for stable isotope analyses. KW, KMS, and EB prepared the paper, created figures, and made tables.

Competing interests. The authors declare that they have no conflict of interest.

Acknowledgements. The authors would like to thank the McMurdo Station support staff, especially those at the Berg Field Center, Petroleum Helicopters International, and the Crary Laboratory, for assistance during the field season. Geoff Hargreaves and crew were of great assistance in subsampling ice cores at the National Ice Core Laboratory. Fred Luiszer (University of Colorado-Boulder) analyzed samples for major ions and Robert Michener (Boston University) analyzed samples for stable isotopes. Useful discussions were had with Maciej Obryk. We also thank the two anonymous reviewers.

Financial support. This research has been supported by the United States National Science Foundation Office of Polar Programs (grant no. 1341284).

Review statement. This paper was edited by Peter Morse and reviewed by two anonymous referees.

\section{References}

Anderson, R. S., Anderson, L. S., Armstrong, W. H., Rossi, M. W., and Crump, S. E.: Glaciation of alpine valleys: The glacier - debris-covered glacier - rock glacier continuum, Geomorphology, 311, 127-142, https://doi.org/10.1016/j.geomorph.2018.03.015, 2018.

Annan, A. P.: GPR methods for hydrogeological studies, in: Hydrogeophysics, edited by: Rubin, Y. and Hubbard, S. S., Springer, Netherlands, 185-213, 2005.

Arcone, S. A., Lawson, D. E., and Delaney, A. J.: Short-pulse radar wavelet recovery and resolution of dielectric contrasts within englacial and basal ice Matanuska Glacier, Alaska, USA, J. Glaciol., 41, 68-86, https://doi.org/10.3189/S0022143000017779, 1995. 
Bao, H., Barnes, J. D., Sharp, Z. D., and Marchant, D. R.: Two chloride sources in soils of the McMurdo Dry Valleys, Antarctica, J. Geophys. Res.-Atmos., 113, 1-10, https://doi.org/10.1029/2007JD008703, 2008.

Bibby, T., Putkonen, J., Morgan, D., Balco, G., and Shuster, D. L.: Million year old ice found under meter thick debris layer in Antarctica, Geophys. Res. Lett., 43, 6995-7001, https://doi.org/10.1002/2016GL069889, 2016.

Brown, J., Harper, J., and Bradford, J.: A radar transparent layer in a temperate valley glacier: Bench Glacier, Alaska, Earth Surf. Process. Landforms, 34, 1497-1506, https://doi.org/10.1002/esp.1835, 2009.

Christ, A. J. and Bierman, P. R.: The local Last Glacial Maximum in McMurdo Sound, Antarctica: Implications for ice-sheet behavior in the Ross Sea Embayment, Geol. Soc. Am. Bull., 1-17, https://doi.org/10.1130/B35139.1, 2019.

Clark, D. H., Steig, E. J., Potter Jr., N., and Gillespie, A. R.: Genetic variability of rock glaciers, Geogr. Ann. A, 80, 175-182, https://doi.org/10.1111/j.0435-3676.1998.00035.x, 1998.

Doran, P. T., Mckay, C. P., Clow, G. D., Dana, G. L., Fountain, A. G., Nylen, T., and Lyons, W. B.: Valley floor climate observations from the McMurdo dry valleys, Antarctica, 1986-2000, J. Geophys. Res., 107, 1-12, https://doi.org/10.1029/2001JD002045, 2002

Fountain, A. G., Nylen, T. H., MacClune, K. L., and Dana, G. L.: Glacier mass balances (1993-2001), Taylor Valley, McMurdo Dry Valleys, Antarctica, J. Glaciol., 52, 451-462, https://doi.org/10.3189/172756506781828511, 2006.

Fountain, A. G., Levy, J. S., Gooseff, M. N., and Van Horn, D.: The McMurdo Dry Valleys: A landscape on the threshold of change, Geomorphology, 225, 25-35, https://doi.org/10.1016/j.geomorph.2014.03.044, 2014.

Fukui, K., Sone, T., Strelin, J. A., Torielli, C. A., Mori, J., and Fujii, Y.: Dynamics and GPR stratigraphy of a polar rock glacier on James Ross Island, Antarctic Peninsula, J. Glaciol., 54, 445-451, https://doi.org/10.3189/002214308785836940, 2008.

Gooseff, M. N., Lyons, W. B., McKnight, D. M., Vaughn, B. H., Fountain, A. G., and Dowling, C.: A Stable Isotopic Investigation of a Polar Desert Hydrologic System, McMurdo Dry Valleys, Antarctica, Arctic, Antarct. Alp. Res., 38, 60-71, https://doi.org/10.1657/15230430(2006)038[0060:ASIIOA]2.0.CO;2, 2006.

Guglielmin, M. and Cannone, N.: A permafrost warming in a cooling Antarctica?, Clim. Change, 111, 177-195, https://doi.org/10.1007/s10584-011-0137-2, 2012.

Hall, B. L. and Denton, G. H.: Radiocarbon chronology of Ross Sea drift, eastern Taylor Valley, Antarctica: Evidence for a grounded ice sheet in the Ross Sea at the last glacial maximum, Geogr. Ann. A, 82, 305-336, https://doi.org/10.1111/j.04353676.2000.00127.x, 2000.

Hall, B. L., Denton, G. H., and Hendy, C. H.: Evidence from Taylor Valley for a Grounded Ice Sheet in the Ross Sea, Antarctica, Geogr. Ann. A., 82, 275-303, https://doi.org/10.1111/j.04353676.2000.00126.x, 2000.

Hamilton, S. J. and Whalley, W. B.: Rock glacier nomenclature: a re-assessment, Geomorphology, 14, 73-80, https://doi.org/10.1016/0169-555X(95)00036-5, 1995.

Hassinger, J. M. and Mayewski, P. A.: Morphology and dynamics of the rock glaciers in southern Victoria Land, Antarctica, Arc- tic Alpine Res., 15, 351-368, https://doi.org/10.2307/1550831, 1983.

Healy, M., Webster-Brown, J. G., Brown, K. L., and Lane, V.: Chemistry and stratification of Antarctic meltwater ponds II: Inland ponds in the McMurdo Dry Valleys, Victoria Land, Antarct. Sci., 18, 525, https://doi.org/10.1017/S0954102006000575, 2006.

Higgins, S. M., Hendy, C. H., and Denton, G. H.: Geochronology of Bonney drift, Taylor Valley, Antarctica: evidence for interglacial expansions of Taylor Glacier, Geogr. Ann. Ser. A, 82, 391-409, https://doi.org/10.1111/1468-0459.00130, 2000.

Hoffman, M. J., Fountain, A. G., and Liston, G. E.: Distributed modeling of ablation (1996-2011) and climate sensitivity on the glaciers of Taylor Valley, Antarctica, J. Glaciol., 65, 215-229, https://doi.org/10.1017/jog.2015.2, 2016.

Holland, H. D.: The chemical evolution of the atmosphere and oceans, Princeton University Press, 585 pp., 1984.

Keys, J. R. and Williams, K.: Origin of crystalline, cold desert salts in the McMurdo region, Antarctica, Geochim. Cosmochim. Ac., 45, 2299-2309, https://doi.org/10.1016/j.limno.2013.04.005, 1981.

Knight, J., Harrison, S., and Jones, D. B: Rock glaciers and the geomorphological evolution of deglacierizing mountains, Geomorphology, 324, 14-24, https://doi.org/10.1016/j.geomorph.2018.09.020, 2018.

Levy, J. S., Fountain, A. G., O'Connor, J. E., Welch, K. A., and Lyons, W. B.: Garwood valley, Antarctica: a new record of last glacial maximum to Holocene glaciofluvial processes in the McMurdo dry valleys, Geol. Soc. Am. Bull., 1, 1484-1502, https://doi.org/10.1130/B30783.1, 2013.

Lyons, W. B., Tyler, S. W., Wharton, R. A., McKnight, D. M., and Vaughn, B. H.: A Late Holocene desiccation of Lake Hoare and Lake Fryxell, McMurdo Dry Valleys, Antarctica, Antarct. Sci., 10, 247-256, https://doi.org/10.1017/S0954102098000340, 1998.

Lyons, W. B., Welch, K. A., Gardner, C. B., Jaros, C., Moorhead, D. L., Knoepfle, J. L., and Doran, P. T.: The geochemistry of upland ponds, Taylor Valley, Antarctica, Antarct. Sci., 24, 3-14, https://doi.org/10.1017/S0954102011000617, 2012.

Macdonell, S. A., Fitzsimons, S. J., and Mölg, T.: Seasonal sediment fluxes forcing supraglacial melting on the Wright Lower Glacier, McMurdo Dry Valleys, Antarctica, Hydrol. Proc., 27, 3192-3207, https://doi.org/10.1002/hyp.9444, 2013.

Mackay, S. L., Marchant, D. R., Lamp, J. L., and Head, J. W.: Cold-based debris-covered glaciers: evaluating the potneital as climate archives through studies of ground-penetraing radar and surface morphology, J. Geophys. Res. Earth, 119, 2505-2540, https://doi.org/10.1002/2014JF003178. Received, 2014.

Marchant, D., Denton, G., Bockheim, J. G., Wilson, S. C., and Kerr, A. R.: Quaternary changes in level of the upper Taylor Glacier, Antarctica: implications for paleoclimate and East Antarctic Ice Sheet dynamics, Boreas, 23, 29-43, https://doi.org/10.1111/j.1502-3885.1994.tb00583.x, 1994.

Naish, T., Powell, R., Levy, R., Wilson, G., Scherer, R., Talarico, F., Krissek, L., Niessen, F., Pompilio, M., Wilson, T., Carter, L., Deconto, R., Huybers, P., Mckay, R., Pollard, D., Ross, J., Winter, D., and Barrett, P.: Obliquity-paced Pliocene West Antarctic ice sheet oscillations, Nature, 458, https://doi.org/10.1038/nature07867, 322-329, 2009. 
Poreda, R. J., Hunt, A. G., Lyons, W. B., and Welch, K. A.: The Helium Isotopic Chemistry of Lake Bonney, Taylor Valley, Antarctica?: Timing of Late Holocene Climate Change in Antarctica, Aquat. Geochem., 10, 353-371, https://doi.org/10.1007/s10498004-2265-z, 2004.

Sandmeier, K. J.: ReflexW Version 5.0. Windows 9x, NT/2000/XPprogram for the processing of seismic, acoustic or electromagnetic reflection, refraction and transmission data, 1-476, 2008.

Shean, D. E. and Marchant, D. R.: Seismic and GPR surveys of Mullins Glacier, mcmurdo dry valleys, Antarctica: Ice thickness, internal structure and implications for surface ridge formation, J. Glaciol., 56, 48-64, https://doi.org/10.3189/002214310791190901, 2010.

Staiger, J. W., Marchant, D. R., Schaefer, J. M., Oberholzer, P., Johnson, J. V., Lewis, A. R., and Swanger, K. M.: PlioPleistocene history of Ferrar Glacier, Antarctica: Implications for climate and ice sheet stability, Earth Planet. Sc. Lett., 243, 489503, https://doi.org/10.1016/j.epsl.2006.01.037, 2006.

Sun, T., Socki, R. A., Bish, D. L., Harvey, R. P., Bao, H., Niles, P. B., Cavicchioli, R., and Tonui, E.: Lost cold Antarctic deserts inferred from unusual sulfate formation and isotope signatures., Nat. Commun., 6, 7579, https://doi.org/10.1038/ncomms8579, 2015.

Swanger, K. M., Marchant, D. R., Schaefer, J. M., Winckler, G., and Head, J. W.: Elevated East Antarctic outlet glaciers during warmer-than-present climates in southern Victoria Land, Glob. Planet. Change, 79, 61-72, https://doi.org/10.1016/j.gloplacha.2011.07.012, 2011.
Swanger, K. M., Lamp, J. L., Winckler, G., Schaefer, J. M., and Marchant, D. R.: Glacier advance during Marine Isotope Stage 11 in the McMurdo Dry Valleys of Antarctica, Sci. Rep., 1-9, https://doi.org/10.1038/srep41433, 2017.

Toner, J. D., Sletten, R. S., and Prentice, M. L.: Soluble salt accumulations in Taylor Valley, Antarctica: implications for paleolakes and Ross Sea Ice Sheet dynamics, J. Geophys. Res.-Earth, 118, 198-215, https://doi.org/10.1029/2012JF002467, 2013.

Wagner, B., Ortlepp, S., Kenig, F., Doran, P. T., and Melles, M.: Palaeoenvironmental implications derived from a piston core from east lobe Bonney, Taylor Valley, Antarctica, Antarct. Sci., 22, 522-530, https://doi.org/10.1017/S0954102010000556, 2010.

Wilch, T. I., Denton, G. H., Lux, D. R., and McIntosh, W. C.: Limited Pliocene glacier extent and surface uplift in middle Taylor Valley, Antarctica, Geogr. Ann. A, 75, 331-351, https://doi.org/10.2307/521206, 1993.

Witherow, R. A., Lyons, W. B., Bertler, N. A. N., Welch, K. A., Mayewski, P. A., Sneed, S. B., Nylen, T., Handley, M. J., and Fountain, A.: The aeolian flux of calcium, chloride and nitrate to the McMurdo Dry Valleys landscape: evidence from snow pit analysis, Antarct. Sci., 18, 497-505, https://doi.org/10.1017/S095410200600054X, 2006.

Yelf, R. and Yelf, D.: Where Is True Time Zero?, Electromagnetic Phenomena, 7, 158-163, https://doi.org/10.1016/j.sjgs.2014.07.006, 2007. 